\title{
Sekapur Sirih Tentang Statistik
}

\author{
Andi Jusmiana \\ Pendidikan Matematika, Universitas Pejuang Republik Indonesia
}

\begin{abstract}
Abstrak
Statistik sebagai suatu ilmu yang mempelajari tentang seluk beluk data yaitu tentang tatacara pengumpulan data, pengolahan data, penganalisaan, penafsiran dan penarikan kesimpulan dari suatu data dalam bentuk angka-angka. Statistik dapat dibagi menjadi beberapa jenis berdasarkan kriteria tertentu., yaitu: 1) Berdasarkan Orientasi Pembahasan, statistik dibagi menjadi statistik matematika dan statistik terapan; 2) berdasarkan fase dan tujuan analisis, dibagi menjadi Statistik deskriptif dan Statistik inferensial; 3) berdasarkan asumsi distribusi populasi data, dibagi menjadi Statistik parametik dan Statistik non-parametrik; dan 4) berdasarkan jumlah variabel terikat, yaitu Statistik univariat dan Statistik multivariat.
\end{abstract}

Kata Kunci: Statistik

\section{Pendahuluan}

Secara etimologis kata Statistika berasal dari bahasa Latin "Status", yang berarti keadaan politik, yang merujuk kepada data politik, data sensus dan data militer, atau berkenaan dengan konstitusional atau aturan. Sehingga statistik bisa didefinisikan sebagai seperangkat metode dan aturan mengenai pengumpulan, analisis, pemrosesan, dan interpretasi data dari angka-angka yang menjelaskan data atau pengamatan. Dengan kata lain, statistik adalah kumpulan data dalam bentuk angka dan disusun dalam bentuk diagram dan/atau tabel di mana isinya menjelaskan masalah tertentu.

Secara umum statistik banyak digunakan dalam studi di berbagai bidang, seperti ekonomi, bisnis, manufaktur, pemasaran, dan lainnya. Dengan statistik itu akan mendapatkan kesimpulan dan memfasilitasi proses pengambilan keputusan.

Pada perkembangan selanjutnya, arti kata statistik hanya dibatasi pada "kumpulan bahan keterangan yang berwujud angka (data kuantitatif)" saja; bahan keterangan yang tidak berwujud angka (data kualitatif) tidak lagi disebut statistik.

Seiring berjalannya waktu kata statistik tidak lagi dibatasi untuk kepentingan-kepentingan Negara saja tapi sudah digunakan dalam keseharian untuk mempermudah masyarakat untuk menganalisis sesuatu yang berkaitan dengan data-data. Sehingga setelah masyarakat memahami statistik dan mulai mempergunakannya dalam kehidupan sehari munculah berbagai macam nama statistik. Statistik yang menjelaskan sesuatu hal biasanya diberi nama statistik mengenai hal yang bersangkutan didalamnya, contohnya kumpulan data yang membahas tentang tingkat produksi suatu perusahaan dinamakan statistik produksi. Banyak persoalan baik itu seperti penelitian ataupun pengamatan yang dinyatakan dalam bentuk bilangan atau angka-angka.

\section{Statistik Menurut Ahli}

Anderson \& Bancroft mengungkapkan bahwa statistik sebagai ilmu \& seni perkembangan juga metode yang paling tepat dan efektif dalam pengumpulan, mentabulasikan dan 
menginterprestasikan data-data kuantitatif (David et al., 1954).

Mood, Graybill \& Boes, statistik merupakan suatu teknologi dari salah satu metode ilmiah dan berkaitan dengan percobaan, penyelidikan dan penarikan kesimpulan (Kass et al., 1974).

Steel \& Torrie mengungkapkan statistik sebagai cara atau metode yang memberikan langkahlangkah guna untuk menilai ketidakpastian dari sebuah kesimpulan yang sifatnya induktif (Fox et al., 1961).

Marguerrite F. Hall mendefinisikan statistik sebagai suatu teknik yang digunakan dalam pengumpulan data, menganalisa, menyimpulkan dan mengadakan penafsiran data dalam bentuk angka (Merrell, 1949).

Mandenhall, statistik adalah salah satu bidang sains yang berhubungan dengan ekstrasi informasi dari sebuah data numerik dan digunakan untuk membuat keputusan dari suatu populasi darimana data itu didapatkan (Miller et al., 1975).

Freund \& Walpole, menjelaskan bahwa statistik sebagai salah satu sains dalam pengambilan suatu keputusan yang belum pasti (Silvey \& Freund, 1972).

Sugiyono menyimpulkan bahwa statistik dalam arti sempit ialah sebagai data dan alat. Secara luas, statistik merupakan suatu alat dalam menganalisis dan mengambil sebuah keputusan (Sugiyono, 2018).

Sudjana, statistik sebagai suatu pengetahuan yang berkaitan dengan teknik-teknik atau caracara pengumpulan data, pengolahan, penganalisaan, penarikan kesimpulan, penyajian data dan publikasi dari data-data dalam bentuk angka (Sudjana, 2005).

Sutrisno Hadi, mengemukakan statistik sebagai salah satu cara untuk mengolah data \& menarik sebuah kesimpulan serta keputusan yang logis dari sebiah pengolahan data (Hadi, 2001).

Agus Irianto, statistik sebagai sekumpulan cara yang berhubungan dengan pengumpulan data, analisis data, penarikan kesimpulan dari datadata yang berbentuk angka dengan menggunakan asumsi tertentu (Irianto, 2004).

Suntoyo Yitnosumarto, statistik sebagai sebuah informasi yang menggunakan metodologi \& cara-cara perhitungan dalam menyelesaikan permasalahan-permasalahan praktis yang muncul (Yitnosumarto \& O’Neill, 1986).

Iqbal Hasan, statistik sebagai suatu ilmu yang mempelajari tentang seluk beluk data yakni tentang tatacara pengumpulan data, pengolahan data, penganalisaan, penafsiran dan penarikan kesimpulan dari suatu data dalam bentuk angkaangka (M. Iqbal, 2002).

Muhammad Arif Tiro, statistika merupakan cara ilmiah untuk mengumpulkan, mengorganisasi, menyajikan dan menganalisis data, serta menarik kesimpulan sahih dan mengambil keputusan layak atas dasar analisisnya (Muhammad Arif Tiro, 2008),.

\section{Manfaat Statistik}

Statistik memiliki manfaat yang sangat besar dalam kehidupan manusia, diantaranya adalah: 1)Dalam kehidupan sehari-hari, statistik tersebut berperan ialah sebagai penyedia bahan atau juga keteranagn dari berbagai hal untuk diolah serta juga ditafsirkan; 2) Dalam penelitian ilmiah, Statistik tersebut dapat berperan ialah sebagai penyedia alat untuk dapata mengemukakan atau pun menemukan kembali keterangan yang seolah tersembunyi dalam angka; 3) Dalam ilmu pengetahuan, statistik tersebut berperan ialah sebagai peralatan analisis juga interprasi diri data kuantitatif ilmu pengetahuan sehingga akan dapat disimpulkan data itu. 


\section{Fungsi Statistik}

Statistik memiliki dua fungsi utama yang sangat penting untuk kegiatan penelitian, diantaranya: 1)Fungsi Deskriptif yaitu untuk menggambarkan, menjelaskan data dan peristiwa, yang dikumpulkan melalui proses penelitian dan investigasi yang belum menggeneralisasi atau menarik kesimpulan tentang populasi yang diteliti; 2)Fungsi Inferensial yaitu untuk memprediksi dan mengendalikan seluruh populasi berdasarkan data, gejala, dan peristiwa dalam proses penelitian. Fungsi ini dimulai dengan membuat estimasi dan hipotesis.

\section{Tujuan Statistik}

Adapun tujuan statistik yaitu: 1) Untuk membuat deskripsi atau menjelaskan data tentang populasi yang sedang diselidiki; 2) Untuk membantu membuat estimasi nilai yang tidak diketahui berdasarkan data yang dianalisis; 3) Untuk membuat perkiraan konsekuensi dari hipotesis yang diterima; 4) Estimasi yang diperoleh dalam statistik, digunakan sebagai dasar untuk pengambilan keputusan; 5) Untuk mengurangi jumlah populasi besar dalam ukuran yang lebih kecil agar lebih mudah dipahami;

\section{Jenis-Jenis Statistik}

Statistik dapat dibagi menjadi beberapa jenis berdasarkan kriteria tertentu.

\section{Berdasarkan Orientasi Pembahasan}

Statistik matematika: statistik yang lebih memahami pemahaman model, rumus statistik matematika-teoritis, penurunan konseptual. Misalnya, tes normalitas, analisis regresi, kesalahan, dan lainnya.

Statistik terapan: statistik yang lebih fokus pada pemahaman konsep, teknik statistik, dan penerapannya dalam disiplin ilmu tertentu.

\section{Berdasarkan Fase dan Tujuan Analisis}

Statistik deskriptif: statistik yang berkaitan dengan pengumpulan pemrosesan, analisis, dan penyajian data tanpa kesimpulan umum. Bentuk statistik ini umumnya dalam bentuk tabel, grafik, diagram, mode, dan sebagainya.

Statistik inferensial: statistik yang prosesnya memungkinkan kesimpulan umum untuk diambil pada data yang sedang diproses.

\section{Berdasarkan Asumsi Distribusi Populasi Data}

Statistik parametik: statistik berdasarkan model distribusi normal.

Statistik non-parametrik: statistik yang dilakukan dengan metode distribusi gratis atau tidak berdasarkan model distribusi normal.

4. Berdasarkan Jumlah Variabel Terikat

Statistik univariat: statistik yang hanya memiliki satu variabel dependen.

Statistik multivariat: statistik yang memiliki lebih dari satu variabel dependen.

\section{DAFTAR PUSTAKA}

David, F. N., Anderson, R. L., \& Bancroft, T. A. (1954). Statistical Theory in Research. Biometrika.

https://doi.org/10.2307/2333033

Fox, R. A., Steel, R. G. D., \& Torrie, J. H. (1961). Principles and Procedures of Statistics with Special Reference to the Biological Sciences. The Incorporated Statistician. https://doi.org/10.2307/2987461

Hadi, S. (2001). Metodologi Research. Universitas Gajah Madha.

Irianto, A. (2004). Statistik Konsep Dasar, Aplikasi dan Pengembangannya. In Standard Methods for the Examination of Water and Wastewater. 
https://doi.org/10.1590/S1516-

18462008000300012

Kass, G. V., Mood, A. M., Graybill, F. A., \& Boes, D. C. (1974). Introduction to the Theory of Statistics, 3rd ed. Journal of the American Statistical Association. https://doi.org/10.2307/2286195

M. Iqbal, H. H. (2002). Pokok-pokok Materi Statistik I ( Statistik Deskriptif). In Statistik deskriptif. https://doi.org/10.1007/b137665

Merrell, M. (1949). Public Health Statistics . Marguerite F. Hall , Paul B. Hoeber . The Quarterly Review of Biology. https://doi.org/10.1086/397325

Miller, R. B., Mendenhall, W., \& Reinmuth, J. E. (1975). Statistics for Management and Economics. Journal of the American Statistical Association. https://doi.org/10.2307/2285466

Muhammad Arif Tiro. (2008). Dasar-dasar Statistik. Andira Publisher.

Silvey, S. D., \& Freund, J. E. (1972). Mathematical Statistics. Journal of the Royal Statistical Society. Series A (General). https://doi.org/10.2307/2344326

Sudjana. (2005). sudjana. In Metoda statistika.

Sugiyono. (2018). Metode Penelitian Kuantitatif,Kualitatif dan R\&D. In ke-26.

Yitnosumarto, S., \& O’Neill, M. E. (1986). ON LEVENE'S TESTS OF VARIANCE HOMOGENEITY. Australian Journal of Statistics. https://doi.org/10.1111/j.1467842X.1986.tb00603.x 